\title{
Diabetes, metabolic syndrome and dyslipidemia in people living with HIV in Africa: re-emerging challenges not to be forgotten
}

This article was published in the following Dove Press journal:

HIVIAIDS - Research and Palliative Care

8 November 2017

Number of times this article has been viewed

\author{
Nazik Elmalaika Husain' \\ Sufian K Noor ${ }^{2}$ \\ Wadie M Elmadhoun ${ }^{3}$ \\ Ahmed O Almobarak ${ }^{4}$ \\ Heitham Awadalla ${ }^{5}$ \\ Clare L Woodward ${ }^{6}$ \\ Dushyant Mital ${ }^{6}$ \\ Mohamed $\mathrm{H} \mathrm{Ahmed}^{7}$ \\ 'Department of Pathology, Faculty \\ of Medicine and Health Sciences, \\ Omdurman Islamic University, \\ Khartoum, ${ }^{2}$ Department of Medicine, \\ ${ }^{3}$ Department of Pathology, Faculty \\ of Medicine and Health Sciences, \\ Nile Valley University, Atbara, \\ ${ }^{4}$ Department of Pathology, Faculty \\ of Medicine, University of Medical \\ Sciences and Technology, ${ }^{5}$ Department \\ of Community Medicine, Faculty of \\ Medicine, University of Khartoum, \\ Khartoum, Sudan; ${ }^{6}$ Department of \\ HIV and Genitourinary Medicine, \\ Milton Keynes University Hospital, \\ NHS Foundation Trust, Milton Keynes, \\ UK; ${ }^{7}$ Department of Medicine and \\ HIV Metabolic Clinic, Milton Keynes \\ University Hospital NHS Foundation \\ Trust, Eaglestone, Milton Keynes, UK
}

Correspondence: Mohamed H Ahmed Department of Medicine and HIV Metabolic Clinic, Milton Keynes University Hospital NHS Foundation Trust, Standing Way, Eaglestone, Milton Keynes MK6 5LD, Buckinghamshire, UK Email elziber@yahoo.com
Background: The current challenge in managing people living with human immunodeficiency virus (PLWHIV) includes the identification and monitoring for comorbid health risks associated with HIV and its treatment and longer survival. Dyslipidemia, diabetes mellitus and metabolic syndrome are increasingly seen in PLWHIV.

Objective: In this narrative review, we aimed to summarize the current knowledge about diabetes, dyslipidemia and metabolic syndrome in PLWHIV in Africa and also to discuss the challenges that patients as well as health authorities in Africa may face.

Methods: PubMed and Google scholar published-English literatures concerning earlier mentioned entities regardless of time limit were critically reviewed.

Results: The prevalence of metabolic disorders in HIV population in Africa was estimated to range from $2.1 \%$ to $26.5 \%$ for diabetes and $20.2 \%$ to $43.5 \%$ for pre-diabetes, $13 \%$ to $58 \%$ for metabolic syndrome and $13 \%$ to $70 \%$ for dyslipidemia.

Conclusion: The management of metabolic disorders and cardiovascular disease risks related to HIV is complex especially in Africa due to healthcare resources, but our experience suggests that metabolic clinic is beneficial to patients and staff and should be an important part of HIV services especially as the older HIV population is increasing. In this context, cardiovascular risk assessment of HIV-infected patients will become an important component of care in developing countries in Africa and strategies are needed to deal with progressive increase in the epidemic of type 2 diabetes, dyslipidemia and metabolic syndrome.

Keywords: dyslipidemia, diabetes mellitus, metabolic syndrome, cardiovascular, NAFLD, HIV services, Africa, metabolic clinic

\section{Introduction}

Despite the fact that combined antiretroviral therapy (cART) for human immunodeficiency virus (HIV) has significantly prolonged the life span of people living with HIV (PLWHIV) and decreased morbidity and mortality, it is associated with an increase in diabetes, dyslipidemia and changes in fat distribution. ${ }^{1}$ The prevalence of diabetes among HIV patients was estimated to be $14 \%$ in 60 adult HIV-infected Black South African individuals who were randomized to either standard-dose (30-40 mg) or lowdose (20-30 mg) stavudine (Bristol-Myers Squibb, New York, NY, USA) or tenofovir disoproxil fumarate (300 mg; Gilead Sciences, Foster City, CA, USA), each combined with lamivudine and efavirenz (Gilead Sciences), for 48 weeks. ${ }^{2} \mathrm{HIV}$ is a condition associated with insulin resistance and lipoatrophy. The risk of insulin resistance can be increased by cART, protease inhibitors (PIs) and some antiretroviral therapy (ART; stavudine and indinavir [Merck Sharp-Dohme, Kenilworth, NJ, USA]). HIV per se is 
thought to lead to a chronic inflammatory state and this in part may lead to glucose intolerance, which adds to the risk of developing insulin resistance. Importantly, the combination of PIs and nucleoside analogs (NRTIs) was shown to increase the risk of type 2 diabetes. $^{3}$

The issue of whether HIV infection is an independent risk factor for diabetes is a subject that requires further research. ${ }^{4-6}$

The Data Collection on Adverse Events of Anti-HIV Drugs (D.A.D.) multicenter study showed that 289 of the 2482 deaths were accounted for by cardiovascular disease (CVD) out of 33,308 patients with HIV. ${ }^{7}$ In this study, they found that in patients with HIV, at baseline, $22 \%$ had total cholesterol $\geq 6.2 \mathrm{mmol} / \mathrm{L}, 34 \%$ had triglycerides $\geq 2.3 \mathrm{mmol} / \mathrm{L}$ and $26 \%$ had high-density lipoprotein cholesterol (HDL-c) $\leq 0.9$ $\mathrm{mmol} / \mathrm{L}$. Furthermore, at baseline, only a few had hypertension (8.5\%) and diabetes mellitus (DM; 2.5\%). Dyslipidemia was recorded in $19.3 \%$ in patients with HIV worldwide. Several studies including meta-analysis concluded that HIV is associated with similar ranges of metabolic syndrome of $17 \%-47 \%$ as in general population. ${ }^{8-10}$ This is important as metabolic syndrome is a strong predictor of CVD and type 2 diabetes. ${ }^{11}$ The D.A.D. study showed a higher prevalence of CVD among HIV patients.

A gamut of variable literature has been published about metabolic syndrome in HIV patients in African nations that need to be grouped to clear the picture. Additionally, the services provided to HIV patients in some low-income African countries are suboptimal.

In this narrative review, we aimed to provide a comprehensive summary of the current knowledge about metabolic syndrome in HIV patients in Africa and discuss the challenges that African patients and authorities may face in providing good services for the aging HIV patients.

\section{Methods}

We reviewed the literature published in PubMed and Google Scholar using the following terms: dyslipidemia, diabetes mellitus, metabolic syndrome, cardiovascular risk and HIV, NAFLD, HIV services, Africa, metabolic clinic and HIV medications.

\section{Diabetes in HIVIAIDS patients in Africa Epidemiology and risk factors}

The number of African people affected by and living with HIV/acquired immunodeficiency syndrome (AIDS) has increased due to the utilization of cART. ${ }^{12,13}$ Though opportunistic infections in HIV patients may lead to serious illness and is one of the causes of mortality, the morbidity and mortality from non-communicable diseases (NCDs) are increasingly becoming important as PLWHIV are surviving longer on therapy. ${ }^{14} \mathrm{DM}$ is a non-transmissible illness with a high prevalence around the world. However, its prevalence, risk factors, pathogenesis and burden in individuals living with or without HIV in Africa are not well studied. ${ }^{15}$

Several studies showed abnormal blood glucose levels or poor control in African HIV-infected patients. ${ }^{16,17}$ The prevalence of disorders of glucose metabolic process in HIV patients was estimated to range from $2.1 \%$ to $26.5 \%$ for diabetes and $20.2 \%$ to $43.5 \%$ for glucose intolerance in some African countries. ${ }^{18-22}$ The prevalence of type $2 \mathrm{DM}$ was found to be $2.1 \%$ (95\% CI 1.3\%-3.2\%) amongst patients living with HIV/AIDS in a public sector facility in Zimbabwe. $^{22}$ The estimated prevalence of diabetes was higher in HIV-negative participants in data from surveyed people aged 50 years and over living with and without HIV in Uganda (471 studied, half of them were HIV positive). ${ }^{15}$ Nevertheless, the prevalence was 5.8\% for DM and 5.6\% for impaired fasting glucose (IFG) among ART-naïve patients having HIV/ AIDS in the main ART center in Guinea-Bissau. ${ }^{18}$

Similarly, Levitt et al compared the prevalence of dysglycemia (IFG, impaired glucose tolerance [IGT] or diabetes) in a cohort of South African participants from a community-based survey (CBS) and three gatherings of HIV/ AIDS people not known to have diabetes. ${ }^{17}$ They reported a prevalence of dysglycemia of $18.0 \%, 21.6 \%, 26.0 \%$ and $37.0 \%$ in CBS participants, ART-naïve patients, patients on non-nucleoside reverse transcriptase inhibitors (NNRTIs) as first-line ART in addition to NRTIs and patients on lopinavir/ ritonavir-boosted PI with added NRTIs as second-line cART, respectively. The authors found that diabetes was comparative crosswise over these gatherings; however, IGT was three- to fourfold higher in second-line cART and CBS compared with ART-naïve and first-line ART groups. ${ }^{17}$

It was found that the duration of HIV infection, large abdominal circumference, ${ }^{19}$ overweight/obesity, sedentary living, low income and lack of information were contributing factors for developing dysglycemia in African populations. ${ }^{23}$ Higher baseline HIV 1 RNA and body mass index (BMI) were also established to be associated with greater risks. ${ }^{24}$ Surprisingly, Tzur et al found that HIV-infected Ethiopians are more likely to develop DM at low BMI values compared to non-Ethiopians. ${ }^{25}$

There is some contradiction concerning older age and female sex as contributing factors for developing dysglycemia in HIV-infected patients. Levitt et al found that the enhanced risk of dysglycemia was related to older age, female 
sex and HIV status (ART-naïve: odds ratio [OR] 2.31, with a 95\% confidence interval [CI] 1.65-3.24; first-line ART: OR 2.47, 95\% CI 1.80-3.38; and second-line ART: OR 4.10, 95\% CI 2.54-6.61). ${ }^{17}$ However, Tzur et al concluded that the comparatively raised prevalence of DM was age-independent but most detectable in those under 42 years. ${ }^{25}$ Alternatively, it has been shown that HIV-infected women on NNRTI-based ART had higher-up glucose tolerance and lower levels of plasma metabolites linked to the developing of diabetes equated with men with alike metabolic disease risk profiles. The association between sex and plasma metabolite levels did not fundamentally differ according to HIV status amongst obese subjects, proposing the observed sex differences may not be HIV-specific. ${ }^{26}$

\section{HIV medications and diabetes}

Presently, cART predominantly used in the management of HIV/AIDS patients includes combinations of PIs and NRTIs, or NNRTIs and NRTIs or just NRTIs. These medications are discussed in relation to their consequences on glucose tolerance and their impact on increasing the risk of acquiring diabetes. There are two newer classes of cART, the CCR5 inhibitors and the integrase inhibitors, ${ }^{27}$ which we have not included in the discussion in this paper.

In spite of its reduction in the burden on HIV/AIDS patients, cART is observed to be connected with insulin resistance, glucose intolerance and type 2 DM..$^{13,27-33}$ PLWHIV on cART have two- to fivefold greater risks for developing DM compared to cART-naïve patients. ${ }^{28,34}$ Disrupted glycemic control in PLWHIV on cART is often attributed to PIs but Efavirenz (an NNRTI utilized as a part of first-line ART regimens in low- and center salary nations); zidovudine (ViiV Healthcare, Brentford, UK) and stavudine have also been associated with an increased risk of developing diabetes. ${ }^{24,35-39}$ Nevertheless, a few studies revealed no significant association between cART duration and metabolic changes in African population. ${ }^{24,31,40,41}$

The increased glucose level in HIV patients on cART can be ascribed to pancreatic beta-cell lipotoxicity, which may represent drug-induced effects, or to the consequences of lipodystrophy or both. ${ }^{42-44}$ In the homeostasis of blood glucose level, insulin supports glucose uptake by activating insulin receptors on cell surfaces. This sets up a course of phosphorylation of key cell substrates that results in translocation of glucose transporter 4 (GLUT4) from the cell cytosol to the surface of the cell, where it encourages glucose entry into the cell. Within this pathway, the action of insulin may be interrupted at numerous points, resulting in insulin resistance. ${ }^{27}$ Several studies have demonstrated that use of the early PIs (such as indinavir) increases insulin resistance. ${ }^{24} \mathrm{~A}$ solitary dosage of the PI indinavir resulted in a 30\% decrease in insulin resistance in healthy HIV-negative subjects, ${ }^{45}$ while PLWHIV prior to the cART era indicated typical insulin activity. ${ }^{46}$

PIs increase insulin resistance through GLUT4-dependent or independent mechanisms. They interfere with the translocation of GLUT4 from the cell cytosol to the surface of the cell. ${ }^{27}$ Furthermore, PIs inhibit adipocyte differentiation by altering adipogenic proteins, such as sterol regulatory element binding protein- $1 .{ }^{47}$ The differentiation of the adipocyte and the secretion of adipokines, (for example, adiponectin) are understood to modulate insulin sensitivity. Interestingly, associations have been additionally seen between leptin and obesity, blood lipids and insulin resistance in an HIV-negative Cameroonian population. ${ }^{48}$ Insulin sensitivity in PLWHIV on cART demonstrates that lipodystrophy is also reduced ${ }^{29,42,49}$ as expected, as lipodystrophy is a known insulin-resistant state.

A small study of PI-treated PLWHIV with lipodystrophy compared to PI-naïve PLWHIV without lipodystrophy (who were matched for age, BMI, and waist) showed increased insulin resistance in the PI-treated lipodystrophic group. ${ }^{49}$ NRTIs additionally add to insulin resistance. ${ }^{50}$ Furthermore, work in healthy HIV-negative controls showed that 4 weeks of stavudine reduced insulin sensitivity connected with decreased mitochondrial DNA and function in muscles. ${ }^{51}$ Diminished expression of mitochondrial genes required for metabolism has likewise been shown in the adipocytes of stavudine-treated HIV-negative controls. ${ }^{52}$ These studies propose that mitochondrial impacts may represent in any event a portion of the metabolic entanglements connected with cART, notwithstanding the notable mitochondrial-related neurological antagonistic impacts.

Adding to cART consequences on peripheral glucose uptake, there is likewise proving of cART impact on insulin secretion. In PLWHIV, who commenced a PI (at the meantime as initiating, or as of now getting, an NRTI), measurements of insulin secretion and beta-cell function decreased by $25 \%-50 \% .^{53}$ Dysfunction of the beta cell (figured by insulin, proinsulin and C-peptide reactions to an oral glucose burden) is described in cART recipients equated with untreated PLWHIV. ${ }^{54}$

Studies of rodent islets and the MIN6 beta-cell culture line have additionally indicated that PIs inhibit glucose sensing and suppress insulin release. ${ }^{55}$ Although mechanisms for these effects are not clear, GLUT2 is a nominee because it is considered to be required for glucose sensing, which is fundamental for the starting out of the pathway of insulin secretion.

Understanding of accessible information demonstrates that PLWHIV on cART are at expanded danger of DM, 
partially added to by class-particular and medication particular antagonistic metabolic impacts, the impacts of lipodystrophy, and the impact of longer survival and increasing weight. Changes in the demographics of PLWHIV will likewise affect, with higher disease rates now occurring in populations who have hereditary liability to $\mathrm{DM} .{ }^{27}$

With the enhanced survival of PLWHIV, NCDs are fast becoming an issue of concern in PLWHIV and also for health systems in Africa especially in low-income settings. ${ }^{15,21,22,56-58}$

Progressively diabetes and other NCDs are developing among low-wage populations that additionally are most burdened by social anxiety and disease..$^{59}$ PLWHIV are at particular risk. ${ }^{58}$ Furthermore, DM commonly causes organspecific damage with exacerbation of the socioeconomic burden. ${ }^{13}$

In the perspective of the expanded danger of dysglycemia in PLWHIV, screening for diabetes and other disorders of glucose metabolism ought to be founded in cART programs in Sub-Saharan Africa. ${ }^{17,18,34}$ Increasing knowledge of healthrelated risk factors is of paramount importance. Further, it justifies equal research attention and financial commitment in the quest for well-being equity. ${ }^{60}$

\section{Metabolic syndrome in HIVIAIDS patients in Africa Epidemiology}

Nguyen et al reported that there was no difference between the prevalence of the metabolic syndrome among HIV patients and the general population in a meta-analysis about global prevalence of metabolic syndrome among HIV patients in a total of 65 studies across the five continents. ${ }^{8}$ Clinical features of the metabolic syndrome include obesity (including visceral obesity), dyslipidemia, hypertension and IGT. Their analysis showed that the prevalence of metabolic syndrome was $16.7 \%-31.3 \%$ among HIV patients and this was almost similar to the prevalence of metabolic syndrome in the general population. Importantly, the duration of diagnosed HIV infection, CD4+ counts, exposure to antiretroviral therapy and use of ART were considered as risk factors for the metabolic syndrome. ${ }^{8}$ Table 1 provides a demonstration of the prevalence of metabolic syndrome in HIV patients in different African countries that ranges from 13\% to 58\%.

\section{Risk factors for the metabolic syndrome among HIV patients}

In South Africa, the prevalence of metabolic syndrome at diagnosis of HIV infection was found to be $8.7 \%$ and increasing to $19.2 \%$ over 36 months $(p=0.001)$.
Table I The prevalence of the metabolic syndrome among HIV patients in some African countries

\begin{tabular}{lll}
\hline Reference & Country & $\begin{array}{l}\text { Prevalence of } \\
\text { metabolic } \\
\text { syndrome }\end{array}$ \\
\hline Gradidge and Crowther $^{61}$ & South Africa & $42 \%$ \\
Sobieszczyk et al ${ }^{62}$ & South Africa & $19.2 \%$ \\
Muyanja et al $^{63}$ & Uganda & $58 \%$ \\
${\text { Guira et a }{ }^{64}}_{\text {Eholié et al }}^{65}$ & Burkina Faso & $18 \%$ \\
Tesfaye et al & Ivory coast & $5.5 \%$ \\
Ayodele et al & Ethiopia & $25 \%$ \\
Zannou et al & Nigeria & $17.2 \%$ \\
\hline Abbreviation & Benin & $13 \%$ \\
\hline
\end{tabular}

Abbreviation: HIV, human immunodeficiency virus.

The proportion of women with obesity increased from $34.4 \%$ to $47.7 \%$; the proportion of women with abnormal waist circumference and elevated blood pressure increased from $33.5 \%$ to $44.3 \%$ and $23.8 \%$ to $43.9 \%$, respectively. Predictors of metabolic syndrome were age, time post-infection and family history of diabetes. ${ }^{62}$

The prevalence of hypertension in patients on cART was twice (38\%) that of the cART-naïve patients in Cameroon (19\%), and risk factors were older age and male sex in the cART group and BMI-defined overweight in the cART-naïve group. ${ }^{69}$ Importantly, in young black Africans, stroke is associated with clusters of the metabolic syndrome. ${ }^{70}$ In Uganda, metabolic syndrome was detected in $58 \%$ of participants and $17 \%$ had a Framingham risk correlating to a $5 \%$ or greater risk for CVD within 10 years. Female sex and over 40 years of age were independently associated with having metabolic syndrome. ${ }^{63}$ Metabolic syndrome was diagnosed in $18 \%$ patients from Burkina Faso. Associated factors were PI regimens, female sex, age $>42$ years $(p=0.001)$ and lipodystrophy $(p=0.01){ }^{64}$

The synergy between HIV, antiretroviral exposure and westernization of lifestyle in a cohort of HIV-infected patients of Sub-Saharan origin leads to a progressive increase in the risk of lipodystrophy, as demonstrated in a study in Ivory Coast (Côte d'Ivoire). The incidence of metabolic syndrome, insulin resistance and lipodystrophy was 5.5, 8.5 and 6.8 per 100 person-years of follow-up (cumulative incidence: $14.4 \%$, $19.2 \%$ and $18.1 \%$, respectively). Risk factors were living in France, female sex and overweight. ${ }^{71}$

Applying the International Diabetes Federation (IDF) criteria, metabolic syndrome was diagnosed in $25 \%$ of patients in Ethiopia receiving ART compared to $22.5 \%$ of the cART-naïve group. On the other hand, using the Adult Treatment Panel III (ATP) criteria, the prevalence of metabolic syndrome was $18.1 \%$ in the cART groups compared 
to $15.6 \%$ in ART-naïve group. Patients receiving cART had significantly elevated cholesterol, triglyceride glucose and low-density lipoprotein cholesterol (LDL-c) levels but lower CD4+ cell counts than the cART-naïve groups. Being a female, having BMI of at least $25 \mathrm{~kg} / \mathrm{m}^{2}$, older age (i.e., age $\geq 45$ years) and having total cholesterol of at least $200 \mathrm{mg}$ / $\mathrm{dl}$ were significantly associated with the presence of metabolic syndrome. ${ }^{66}$ In another study from Ethiopia, 18\% had subclinical atherosclerosis; of whom $14 \%$ were ART-naïve whereas $24 \%$ were ART-treated. Independent predictors of subclinical atherosclerosis included age per 5-year increase in age, BMI and high LDL. High-sensitivity C-reactive protein was positively correlated with traditional cardiometabolic risk factors including waist circumference, triglycerides and total cholesterol:HDL ratio (TC:HDL) $(r=0.225, p<0.001)$. Risk factors for lipodystrophy in Ethiopia were a history of smoking, cART regimen and duration of cART treatment. ${ }^{72}$

In this regard, longitudinal studies with longer follow-up showed a high prevalence of metabolic complications. For example, in Senegal, after a median of 9 years of cART, $37 \%$ had lipodystrophy, $28 \%$ had hypertension and $14 \%$ presented with diabetes. ${ }^{73}$ Despite the fact that physical activity is regarded as a best treatment for metabolic syndrome, PLWHIV in Africa demonstrate low physical activity. For example, in Rwanda in a cohort of 407 patients with HIV, approximately $70 \%$ were inactive, $40 \%$ were obese and $43 \%$ were overweight. Obesity was strongly associated with inactivity. Lack of motivation and time, as well as fear of worsening the disease, were found to be barriers to participation in physical activity programs. ${ }^{74}$ Therefore, high levels of metabolic complications are seen in an African population. For instance, in Cameroon, the high prevalence of diabetes, dyslipidemia, metabolic syndrome, arterial and aortic stiffness were noticed in PLWHIV in comparison with the general population. ${ }^{75}$

The use of different criteria in the diagnosis of metabolic syndrome is known as a cause for variations in the prevalence of metabolic syndrome. For instance, in a study in Nigeria, the prevalence of metabolic syndrome according to the ATP III, IDF and JIS criteria were $12.7 \%$, $17.2 \%$ and $21.0 \%$, respectively. Metabolic syndrome was significantly associated with female sex (all definitions), BMI (all definitions), increasing age and CD4 count (IDF definition). There was no significant association between metabolic syndrome and cART. ${ }^{67}$ Furthermore, metabolic syndrome in Benin (IDF definition) appeared in $13 \%$ and was more common in women ( $19.2 \%$ versus $3.1 \%$ in men). Diabetes (8\%) and hypercholesterolemia (35\%) were also observed. After adjustment, sex, young age (hazard ratio [HR] 0.45 [95\% CI 0.22-0.90]; $p=0.025$ ), high BMI at inclusion (HR 1.53 [95\% CI 1.28-1.83]; $p<0.0001$ ) and smoking (HR 28.0 [95\% CI 2.5-307.4]; $p=0.006$ ) were significantly associated with lipohypertrophy. In this study, $30 \%$ patients developed lipodystrophy (lipoatrophy $9 \%$, lipohypertrophy $24 \%$ and mixed pattern $2.5 \%$ ). The incidence rate for lipodystrophy was estimated to 1.72 per person-month $(95 \% \mathrm{CI}$ 1.15-2.56) occurring after a median time of 11 months on cART. ${ }^{68}$ Importantly, moderate-severe lipodystrophy affected one-third of West African patients on long-term cART, and stavudine administration was the only independent risk factor. Other associated risk factors were insulin resistance and central obesity and high triglyceride..$^{72,73,76}$

\section{Dyslipidemia in HIVIAIDS patients in Africa}

Dyslipidemia is very common in PLWHIV and manifests as low HDL, high triglyceride, total cholesterol and LDL-c. Table 2 shows the prevalence and types of dyslipidemia associated with HIV drugs in some African countries. It is well established that cardiovascular risk assessment of HIVinfected patients is a critical element of care in developed countries, and health care systems that provide antiretroviral therapy in African countries would also benefit from lipid specialists in order to reduce CVD in HIV patients.

Among PLWHIV in South Africa, hypercholesterolemia was found in $32.2 \%$, low HDL-c in $45.7 \%$ and elevated LDL-c in 9.5\% (95\% CI 6.2-12.8). TC and LDL-c were positively correlated with CD4+ cell count ${ }^{80}$ This is likely due to the effect of medications, as ART administration is associated with higher TG, TC, LDL-c and HDL-c than those who were ART-naïve.$^{81}$ Higher prevalence of dyslipidemia was also reported in other African countries. For instance, in Kenya, the prevalence of dyslipidemia was $63.1 \%$ and dysglycemia was $20.7 \%$. HAART was associated with high total and LDL-c and high triglyceride levels. However, HAART is not associated with low HDL-c and had no effect on dysglycemia. In Nigeria, high cholesterol, LDL-c and triglyceride were seen in $28 \%, 24 \%$ and $35 \%$, respectively. It is reported that PI worsens dyslipidemia. ${ }^{82,83}$ In Tanzania, low HDL-c was prevalent in $67 \%$ and increased triglyceride in $28 \%$. High triglyceride and low HDL levels were associated with low CD4+ counts $(p<0.001) .{ }^{77}$ The prevalence of dyslipidemia in Malawi, Ethiopia and Cameroon was estimated to be $31 \%$, $56.9 \%$ and $70.2 \%$, respectively. ${ }^{72,77,78}$

Dyslipidemia is largely related to CD4+ cell count, PI, fatty liver and use of ART. Importantly, HAART was 
Table 2 The prevalence and type of dyslipidemia associated with HIV medications in some African countries.

\begin{tabular}{|c|c|c|c|c|c|c|}
\hline Reference & Country & Type of study & Study population & Dyslipidemia & Prevalence & Main conclusion \\
\hline Dave et a ${ }^{80}$ & $\begin{array}{l}\text { South Africa - } \\
\text { Cape Town }\end{array}$ & $\begin{array}{l}\text { A cross- } \\
\text { sectional study }\end{array}$ & $\begin{array}{l}406 \text { adult ART- } \\
\text { naïve and 55I adult } \\
\text { HIV participants } \\
\text { receiving NNRTI*- } \\
\text { based or PI**- } \\
\text { based ART }\end{array}$ & $\begin{array}{l}\text { High TG, TC, } \\
\text { LDL-c and low } \\
\text { HDL-c }\end{array}$ & $90.0 \%$ and $85 \%$, respectively & $\begin{array}{l}\text { Dyslipidemia likely to } \\
\text { occur with ART more } \\
\text { than with ART-naïve }\end{array}$ \\
\hline Julius et $\mathrm{a}^{81}$ & $\begin{array}{l}\text { South Africa - } \\
\text { Johannesburg }\end{array}$ & $\begin{array}{l}\text { A cross- } \\
\text { sectional study }\end{array}$ & $\begin{array}{l}304 \text { HIV adult } \\
\text { patients on } \\
\text { HAART for more } \\
\text { than I year }\end{array}$ & $\begin{array}{l}\text { High TG, TC, } \\
\text { LDL-c and low } \\
\text { HDL-c }\end{array}$ & $\begin{array}{l}\text { Hypertriglyceridemia }(>2.25 \mathrm{mmol} \\
(\mathrm{mL}) \text { in } 15.8 \% \text {, hypercholesterolemia } \\
(\mathrm{TC}>5.00 \mathrm{mmol} / \mathrm{mL}) \text { in } 32.2 \% \text {, } \\
\text { low HDL-c }(<1.20 \mathrm{mmol} / \mathrm{mL}) \\
\text { in } 45.7 \% \text { and elevated } \mathrm{LDL}-\mathrm{c} \\
(>4.10 \mathrm{mmol} / \mathrm{mL}) \text { in } 9.5 \%\end{array}$ & $\begin{array}{l}\text { ART administration } \\
\text { is associated with } \\
\text { dyslipidemia }\end{array}$ \\
\hline $\begin{array}{l}\text { Manuthu } \\
\text { et } \mathrm{al}^{40}\end{array}$ & Kenya & $\begin{array}{l}\text { A cross- } \\
\text { sectional } \\
\text { comparative } \\
\text { group study }\end{array}$ & $\begin{array}{l}295 \text { HIV adult } \\
\text { patients; I } 34(45 \%) \\
\text { were on HAART, } \\
82 \% \text { of whom } \\
\text { were on stavudine, } \\
\text { lamivudine and } \\
\text { either nevirapine } \\
\text { or efavirenz }\end{array}$ & $\begin{array}{l}\text { High TG, TC, } \\
\text { LDL-c and low } \\
\text { HDL-c }\end{array}$ & 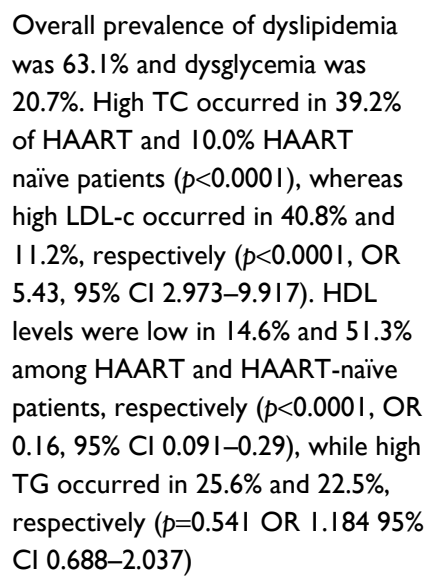 & $\begin{array}{l}\text { HAART was } \\
\text { associated with high } \\
\text { total cholesterol } \\
\text { and LDL-c and high } \\
\text { triglyceride levels. } \\
\text { However, HAART } \\
\text { was not associated } \\
\text { with low HDL-c and } \\
\text { had no effect on } \\
\text { dysglycemia }\end{array}$ \\
\hline Lesi et a $\left.\right|^{82}$ & Nigeria - Lagos & $\begin{array}{l}\text { A prospective } \\
\text { cross-sectional } \\
\text { study }\end{array}$ & $\begin{array}{l}\text { II } 3 \text { adult HIV } \\
\text { patients on } \\
\text { HAART therapy } \\
\text { for } 6-42 \text { months }\end{array}$ & $\begin{array}{l}\text { High TG, TC, } \\
\text { LDL-c and low } \\
\text { HDL-c }\end{array}$ & $\begin{array}{l}\text { Fatty liver prevalence was } 13.3 \% \text {. } \\
\text { High cholesterol, LDL-c and TG } \\
\text { were seen in } 28 \%, 24 \% \text { and } 35 \% \text {, } \\
\text { respectively }\end{array}$ & $\begin{array}{l}\text { Hepatic steatosis was } \\
\text { strongly associated } \\
\text { with hepatomegaly } \\
\text { and hyperlipidemia in } \\
\text { subjects on long-term } \\
\text { HAART }\end{array}$ \\
\hline Salami et $a^{83}$ & Nigeria - Ilorin & & $\begin{array}{l}\text { I } 27 \text { HIV adult } \\
\text { patients; } 94(29 \%) \\
\text { on PI and } 233 \\
\text { (7I\%) on NNRTI } \\
\text { regular treatment } \\
\text { for at least } \\
3 \text { months }\end{array}$ & $\begin{array}{l}\text { Low HDL, high } \\
\text { triglyceride, } \\
\text { cholesterol and } \\
\text { LDL-c }\end{array}$ & $\begin{array}{l}\text { The pretreatment metabolic } \\
\text { changes in both groups (PI vs. } \\
\text { NNRTI) were low HDL-c; } 29 \\
(31 \%) \text { vs. } 77 \text { ( } 33 \%) \text {, followed by } \\
\text { hypertriglyceridemia; I6 (I7\%) vs. } \\
38(16 \%) \text { and hypercholesterolemia; } \\
6(6 \%) \text { vs. } 10 \text { (4\%). After exposure } \\
\text { to two different HAART } \\
\text { regimens, hypertriglyceridemia } \\
\text { and hypercholesterolemia became } \\
\text { more prevalent especially with } \\
\text { PI-based therapy than NNRTI; } 74 \\
(79 \%) \text { vs. } 108 \text { (54\%) and } 58(5 I \%) \\
\text { vs. } 72(31 \%)\end{array}$ & $\begin{array}{l}\text { HARRT treatment, } \\
\text { especially PI, } \\
\text { worsened } \\
\text { dyslipidemia ( } 3 \text { times) }\end{array}$ \\
\hline $\begin{array}{l}\text { Armstrong } \\
\text { et } \mathrm{al}^{77}\end{array}$ & Tanzania & $\begin{array}{l}\text { A cross- } \\
\text { sectional study }\end{array}$ & $\begin{array}{l}\text { I2,5 I } 3 \text { ART-naïve, } \\
\text { non-fasting HIV } \\
\text { adult patients }\end{array}$ & $\begin{array}{l}\text { High TG, TC, } \\
\text { LDL-c and low } \\
\text { HDL-c }\end{array}$ & $\begin{array}{l}\text { Low HDL-c was prevalent in } 67 \% \\
\text { and increased TG in } 28 \%\end{array}$ & $\begin{array}{l}\text { Dyslipidemia was } \\
\text { associated with } \\
\text { low CD4 counts } \\
(p<0.00 \text { I })\end{array}$ \\
\hline
\end{tabular}


Table 2 (Continued)

\begin{tabular}{|c|c|c|c|c|c|c|}
\hline Reference & Country & Type of study & Study population & Dyslipidemia & Prevalence & Main conclusion \\
\hline $\begin{array}{l}\text { Muronya } \\
\text { et } a^{84}\end{array}$ & Malawi & $\begin{array}{l}\text { A cross- } \\
\text { sectional study }\end{array}$ & $\begin{array}{l}\text { I74 HIV adult } \\
\text { patients on long- } \\
\text { term (>I year) } \\
\text { ART }\end{array}$ & High cholesterol & $\begin{array}{l}\text { High TC levels }(31.0 \%) \text {, raised blood } \\
\text { pressure }(45.9 \%) \text {, increased waist- } \\
\text { hip ratio }(45.4 \%)\end{array}$ & $\begin{array}{l}\text { Cardiovascular risk } \\
\text { factors were commor } \\
\text { among long-term } \\
\text { ART patients in } \\
\text { Malawi }\end{array}$ \\
\hline Feleke et $\mathrm{al}^{72}$ & $\begin{array}{l}\text { Ethiopia - } \\
\text { Addis Ababa }\end{array}$ & $\begin{array}{l}\text { A cross- } \\
\text { sectional study }\end{array}$ & $\begin{array}{l}356 \text { HIV adult } \\
\text { patients on } \\
\text { HAART for I } \\
\text { year or more. } 209 \\
(59.7 \%) \text { patients } \\
\text { were on stavudine- } \\
\text { based ART } \\
\text { therapy and I } 35 \\
\text { ( } 41.3 \%) \text { were on } \\
\text { zidovudine-based } \\
\text { ART therapy }\end{array}$ & $\begin{array}{l}\text { High TG, TC, } \\
\text { LDL-c and low } \\
\text { HDL-c }\end{array}$ & $\begin{array}{l}\text { Prevalence of hyperlipidemia } \\
\text { was } 56.9 \% \text {, prevalence of } \\
\text { hypercholesterolemia was } 38.2 \% \text {, } \\
\text { prevalence of high LDL-c } 54.2 \% \text {, } \\
\text { prevalence of hypertriglyceridemia } \\
\text { was } 15.2 \% \text {, prevalence of fasting } \\
\text { hyperglycemia was } 17.8 \%\end{array}$ & $\begin{array}{l}\text { Lipodystrophies } \\
\text { occurred in majority } \\
\text { of patients on } \\
\text { ART treatment for } \\
\text { longer than I year; } \\
\text { hyperlipidemia and } \\
\text { hyperglycemia were } \\
\text { also seen commonly } \\
\text { in Ethiopian HIV } \\
\text { patients on HAART }\end{array}$ \\
\hline Bekolo et a $\mathrm{l}^{78}$ & Cameroon & $\begin{array}{l}\text { A cross- } \\
\text { sectional study }\end{array}$ & $\begin{array}{l}\text { II } 4 \text { HIV-infected } \\
\text { persons aged I5 } \\
\text { years or more and } \\
\text { receiving first-line } \\
\text { ART for at least } 6 \\
\text { months }\end{array}$ & $\begin{array}{l}\text { High TG, TC, } \\
\text { LDL-c and low } \\
\text { HDL-c }\end{array}$ & $\begin{array}{l}\text { Prevalence of hyperlipidemia } \\
\text { was } 70.2 \% \text {, prevalence of } \\
\text { hypercholesterolemia was } 29.8 \% \text {, } \\
\text { prevalence of high LDL-c was } 30 \% \text {, } \\
\text { prevalence of hypertriglyceridemia } \\
\text { was } 51.8 \%\end{array}$ & $\begin{array}{l}\text { A high prevalence of } \\
\text { dyslipidemia in HIV } \\
\text { patients receiving } \\
\text { first-line ART was } \\
\text { found }\end{array}$ \\
\hline
\end{tabular}

Abbreviations: ART, antiretroviral therapy; Cl, confidence interval; HDL-c, high-density lipoprotein cholesterol; HIV, human immunodeficiency virus; LDL-c, low-density lipoprotein cholesterol; NNRTI, non-nucleoside reverse transcriptase inhibitor; OR, odds ratio; PI, protease inhibitor; TC, total cholesterol; TG, triglyceride.

associated with lipodystrophy, and the risk of developing type II diabetes among the HAART-experienced group was 5 times higher than the HAART-naïve group. ${ }^{79}$

\section{Conclusion}

PLWHIV live longer and are increasingly encountering a series of challenging metabolic disorders like diabetes, obesity, dyslipidemia and subsequent increase in the risk of CVD. Dyslipidemia can be due to HIV infection or induced by HIV medications. Furthermore, in African countries, CVD has become one of the major causes of death in HIV patients due to the high prevalence of diabetes, dyslipidemia and metabolic syndrome. Therefore, cardiovascular risk reduction and lifestyle modifications are essential components for the control program; and careful selection of the antiretroviral drugs according to underlying cardiovascular risk factors is of great importance. In the view of the fact that PLWHIV are an expanding and aging population to address, a metabolic clinic may be a good choice for African countries not only to meet the clinical demand for clinical services but also to provide a useful opportunity to collect data for future clinical research (see Ahmed et $\mathrm{al}^{85}$ for further information about HIV metabolic clinic in Milton Keynes University Hospital, UK).

\section{Disclosure}

The authors report no conflicts of interest in this work.

\section{References}

1. Husain NE, Ahmed MH. Managing dyslipidemia in HIV/AIDS patients: challenges and solutions. Hiv/Aids. 2015;7:1-10.

2. Menezes CN, Crowther NJ, Duarte R, et al. A randomized clinical trial comparing metabolic parameters after 48 weeks of standard- and low-dose stavudine therapy and tenofovir disoproxil fumarate therapy in HIV-infected South African patients. HIV Med. 2014;15(1):3-12.

3. Ledergerber B, Furrer H, Rickenbach M, et al; Swiss HIV Cohort Study. Factors associated with the incidence of type 2 diabetes mellitus in HIV-infected participants in the Swiss HIV Cohort Study. Clin Infect Dis. 2007;45(1):111-119.

4. Tripathi A, Jerrell JM, Liese AD, et al. Association of clinical and therapeutic factors with incident dyslipidemia in a cohort of human immunodeficiency virus-infected and non-infected adults: 1994-2011. Metab Syndr Relat Disord. 2013;11(6):417-426.

5. Wang KL, Liu CJ, Chao TF, et al. Statins, risk of diabetes, and implications on outcomes in the general population. $\mathrm{J} \mathrm{Am} \mathrm{Coll} \mathrm{Cardiol.}$ 2012;60(14):1231-1238.

6. Ridker PM, Pradhan A, MacFadyen JG, Libby P, Glynn RJ. Cardiovascular benefits and diabetes risks of statin therapy in primary prevention: an analysis from the JUPITER trial. Lancet. 2012;380(9841):565-571.

7. Smith C, Sabin CA, Lundgren JD, et al; Data Collection on Adverse Events of Anti-HIV drugs (D:A:D) Study Group. Factors associated with specific causes of death amongst HIV-positive individuals in the D:A:D Study. AIDS. 2010;24(10):1537-1548.

8. Nguyen KA, Peer N, Mills EJ, Kengne AP. A meta-analysis of the metabolic syndrome prevalence in the global HIV-infected population. PLoS One. 2016;11(3): 0150970. 
9. Grundy SM. Metabolic syndrome pandemic. Arterioscler Thromb Vasc Biol. 2008;28(4):629-636.

10. Márquez-Sandoval F, Macedo-Ojeda G, Viramontes-Hörner D, Fernández Ballart JD, Salas Salvadó J, Vizmanos B. The prevalence of metabolic syndrome in Latin America: a systematic review. Public Health Nutr. 2011;14(10):1702-1713.

11. Gami AS, Witt BJ, Howard DE, et al. Metabolic syndrome and risk of incident cardiovascular events and death: a systematic review and meta-analysis of longitudinal studies. J Am Coll Cardiol. 2007;49(4): 403-414.

12. Edwards JK, Bygrave H, Van den Bergh R, et al. HIV with noncommunicable diseases in primary care in Kibera, Nairobi, Kenya: characteristics and outcomes 2010-2013. Trans R Soc Trop Med Hyg. 2015;109:440-446.

13. Hadigan C, Kattakuzhy S. Diabetes mellitus type 2 and abnormal glucose metabolism in the setting of human immunodeficiency virus. Endocrinol Metab Clin North Am. 2014;43(3):685-696.

14. Watkins DA, Tulloch NL, Anderson ME, Barnhart S, Steyn K, Levitt NS. Delivery of health care for cardiovascular and metabolic diseases among people living with HIV/AIDS in African countries: a systematic review protocol. Syst Rev. 2016;5:63.

15. Mugisha JO, Schatz EJ, Randell M, et al. Chronic disease, risk factors and disability in adults aged 50 and above living with and without HIV: findings from the Well-being of Older People Study in Uganda. Glob Health Action. 2016;9:31098.

16. Pillay S, Aldous C, Mahomed F. A deadly combination - HIV and diabetes mellitus: Where are we now? SAfr Med J. 2016;106(4):54.

17. Levitt NS, Peer N, Steyn K, et al. Increased risk of dysglycaemia in South Africans with HIV; especially those on protease inhibitors. Diabetes Res Clin Pract. 2016;119:41-47.

18. Steiniche, D, Jespersen S, Erikstrup C, et al; Bissau HIV Cohort Study Group. Diabetes mellitus and impaired fasting glucose in ART-naive patients with HIV-1, HIV-2 and HIV-1/2 dual infection in Guinea-Bissau: a cross-sectional study. Trans R Soc Trop Med Hyg. 2016;110(4):219-227.

19. Rhee JY, Bahtila TD, Palmer D, et al. Prevalence of and factors associated with prediabetes and diabetes among HIV-infected adults in Cameroon. Diabetes Metab Res Rev. 2016;32(6):544-549.

20. Abrahams Z, Dave JA, Maartens G, Levitt NS. Changes in blood pressure, glucose levels, insulin secretion and anthropometry after long term exposure to antiretroviral therapy in South African women. AIDS Res Ther. 2015;12:24.

21. Khabala KB, Edwards JK, Baruani B, et al. Medication adherence clubs: a potential solution to managing large numbers of stable patients with multiple chronic diseases in informal settlements. Trop Med Int Health. 2015;20(10):1265-1270.

22. Magodoro IM, Esterhuizen TM, Chivese T. A cross-sectional, facility based study of comorbid non-communicable diseases among adults living with HIV infection in Zimbabwe. BMC Res Notes. 2016; 9:379.

23. Adeniyi OV, Yogeswaran P, Longo-Mbenza B, Ter Goon D, Ajayi AI. Cross-sectional study of patients with type 2 diabetes in OR Tambo district, South Africa. BMJ Open. 2016;6:e010875.

24. Erlandson KM, Kitch D, Tierney C, et al. Impact of randomized antiretroviral therapy initiation on glucose metabolism. AIDS. 2014;28(10): $1451-1461$.

25. Tzur F, Chowers M, Agmon-Levin N, MekoriYA, Hershko AY. Increased prevalence of diabetes mellitus in a non-obese adult population: HIVinfected Ethiopians. Isr Med Assoc J. 2015;17(10):620-623.

26. Koethe JR, Jenkins CA, Petucci C, Culver J, Shepherd BE, Sterling TR. Superior glucose tolerance and metabolomic profiles, independent of adiposity, in HIV-infected women compared with men on antiretroviral therapy. Medicine (Baltimore). 2016;95(19):e3634.

27. Samaras K. Prevalence and pathogenesis of diabetes mellitus in HIV-1 infection treated with combined antiretroviral therapy. JAcquir Immune Defic Syndr. 2009;50(5):499-505.
28. Dimala CA, Atashili J, Mbuagbaw JC, Wilfred A, Monekosso GL. A comparison of the diabetes risk score in HIV/AIDS patients on highly active antiretroviral therapy (HAART) and HAART-naive patients at the Limbe Regional Hospital, Cameroon. PLoS One. 2016;11(5):e0155560.

29. Carr A, Samaras K, Thorisdottir A, Kaufmann GR, Chisholm DJ, Cooper DA. Diagnosis, prediction, and natural course of HIV-1 proteaseinhibitor-associated lipodystrophy, hyperlipidaemia, and diabetes mellitus: a cohort study. Lancet. 1999;353(9170):2093-2099.

30. Murata H, Hruz PW, Mueckler M. The mechanism of insulin resistance caused by HIV protease inhibitor therapy. $J$ Biol Chem. 2000;275(27):20251-20254.

31. Dave JA, Lambert EV, Badri M, West S, Maartens G, Levitt NS. Effect of nonnucleoside reverse transcriptase inhibitor-based antiretroviral therapy on dysglycemia and insulin sensitivity in South African HIVinfected patients. J Acquir Immune Defic Syndr. 2011;57(4):284-289.

32. De Wit S, Sabin CA, Weber R, et al; Data Collection on Adverse Events of Anti-HIV Drugs (D:A:D) study. Incidence and risk factors for new-onset diabetes in HIV-infected patients: the Data Collection on Adverse Events of Anti-HIV Drugs (D:A:D) study. Diabetes Care. 2008;31(6):1224-1229.

33. Rasmussen LD, Mathiesen ER, Kronborg G, Pedersen C, Gerstoft J, Obel N. Risk of diabetes mellitus in persons with and without HIV: a Danish nationwide population-based cohort study. PLoS One. 2012;7(9):e44575.

34. Maganga E, Smart LR, Kalluvya S, et al. Glucose metabolism disorders, HIV and antiretroviral therapy among Tanzanian adults. PLoS One. 2015;10(8):e0134410.

35. Martinez E, Arnaiz JA, Podzamczer D, et al; Nevirapine, Efavirenz, and Abacavir (NEFA) Study Team. Substitution of nevirapine, efavirenz, or abacavir for protease inhibitors in patients with human immunodeficiency virus infection. $N$ Engl J Med. 2003;349(11):1036-1046.

36. Jemsek JG, Arathoon E, Arlotti M, et al. Body fat and other metabolic effects of atazanavir and efavirenz, each administered in combination with zidovudine plus lamivudine, in antiretroviral-naive HIV-infected patients. Clin Infect Dis. 2006;42(2):273-280.

37. Lennox JL, Dejesus E, Berger DS, et al; STARTMRK Investigators. Raltegravir versus Efavirenz regimens in treatment-naive HIV1-infected patients: 96-week efficacy, durability, subgroup, safety, and metabolic analyses. J Acquir Immune Defic Syndr. 2010;55(1):39-48.

38. Fisac C, Fumero E, Crespo M, et al. Metabolic benefits 24 months after replacing a protease inhibitor with abacavir, efavirenz or nevirapine. AIDS. 2005;19(9):917-925.

39. Karamchand S, Leisegang R, Schomaker M, et al. Risk factors for incident diabetes in a cohort taking first-line nonnucleoside reverse transcriptase inhibitor-based antiretroviral therapy. Medicine (Baltimore). 2016;95(9):e2844.

40. Manuthu EM, Joshi MD, Lule GN, Karari E. Prevalence of dyslipidemia and dysglycaemia in HIV infected patients. East Afr Med J. 2008;85(1):10-17.

41. Ekali LG, Johnstone LK, Echouffo-Tcheugui JB, et al. Fasting blood glucose and insulin sensitivity are unaffected by HAART duration in Cameroonians receiving first-line antiretroviral treatment. Diabetes Metab. 2013;39(1):71-77.

42. Carr A, Samaras K, Burton S, et al. A syndrome of peripheral lipodystrophy, hyperlipidaemia and insulin resistance in patients receiving HIV protease inhibitors. AIDS. 1998;12(7):F51-F58.

43. Carr A, Samaras K, Chisholm DJ, Cooper DA. Pathogenesis of HIV1-protease inhibitor-associated peripheral lipodystrophy, hyperlipidaemia, and insulin resistance. Lancet. 1998;351(9119):1881-1883.

44. Gan SK, Samaras K, Carr A, Chisholm D. Anti-retroviral therapy, insulin resistance and lipodystrophy. Diabetes Obes Metab. 2001;3(2):67-71.

45. Noor MA, Seneviratne T, Aweeka FT, et al. Indinavir acutely inhibits insulin-stimulated glucose disposal in humans: a randomized, placebocontrolled study. AIDS. 2002;16(5):F1-F8.

46. Hommes MJ, Romijn JA, Endert E, Eeftinck Schattenkerk JK, Sauerwein HP. Insulin sensitivity and insulin clearance in human immunodeficiency virus-infected men. Metabolism. 1991;40(6):651-656. 
47. Caron M, Auclair M, Vigouroux C, Glorian M, Forest C, Capeau J. The HIV protease inhibitor indinavir impairs sterol regulatory elementbinding protein-1 intranuclear localization, inhibits preadipocyte differentiation, and induces insulin resistance. Diabetes. 2001;50(6): 1378-1388.

48. Ayina CN, Noubiap JJ, Etoundi Ngoa LS, et al. Association of serum leptin and adiponectin with anthropomorphic indices of obesity, blood lipids and insulin resistance in a Sub-Saharan African population. Lipids Health Dis. 2016;15:96.

49. Gan SK, Samaras K, Thompson $\mathrm{CH}$, et al. Altered myocellular and abdominal fat partitioning predict disturbance in insulin action in HIV protease inhibitor-related lipodystrophy. Diabetes. 2002;51(11): 3163-3169.

50. Blumer RM, van Vonderen MG, Sutinen J, et al. Zidovudine/lamivudine contributes to insulin resistance within 3 months of starting combination antiretroviral therapy. AIDS. 2008;22(2):227-236.

51. Fleischman A, Johnsen S, Systrom DM, et al. Effects of a nucleoside reverse transcriptase inhibitor, stavudine, on glucose disposal and mitochondrial function in muscle of healthy adults. Am J Physiol Endocrinol Metab. 2007;292(6):E1666-E1673.

52. Mallon PW, Unemori P, Sedwell R, et al; SAMA Investigators. In vivo, nucleoside reverse-transcriptase inhibitors alter expression of both mitochondrial and lipid metabolism genes in the absence of depletion of mitochondrial DNA. J Infect Dis. 2005;191(10):1686-1696.

53. Woerle HJ, Mariuz PR, Meyer C, et al. Mechanisms for the deterioration in glucose tolerance associated with HIV protease inhibitor regimens. Diabetes. 2003;52(4):918-925.

54. Behrens G, Dejam A, Schmidt H, et al. Impaired glucose tolerance, beta cell function and lipid metabolism in HIV patients under treatment with protease inhibitors. AIDS. 1999;13(10):F63-F70.

55. Koster JC, Remedi MS, Qiu H, Nichols CG, Hruz PW. HIV protease inhibitors acutely impair glucose-stimulated insulin release. Diabetes. 2003;52(7):1695-1700.

56. Winchester MS, BeLue R, Oni T, et al. The Pan-University Network for Global Health: framework for collaboration and review of global health needs. Global Health. 2016;12:13.

57. Mendenhall E, Norris SA. When HIV is ordinary and diabetes new: remaking suffering in a South African township. Glob Public Health. 2015;10(4):449-462

58. Kagaruki GB, Mayige MT, Ngadaya ES, et al. Magnitude and risk factors of non-communicable diseases among people living with HIV in Tanzania: a cross sectional study from Mbeya and Dar es Salaam regions. BMC Public Health. 2014;14:904.

59. Mendenhall E, Omondi GB, Bosire E, et al. Stress, diabetes, and infection: syndemic suffering at an urban Kenyan hospital. Soc Sci Med. 2015;146:11-20.

60. Dagadu HE, Patterson EJ. Placing a health equity lens on non-communicable diseases in sub-Saharan Africa. J Health Care Poor Underserved. 2015;26(3):967-989.

61. Gradidge PJ, Crowther NJ. Review: metabolic syndrome in Black South African Women. Ethn Dis. 2017;27(2):189-200.

62. Sobieszczyk ME, Werner L, Mlisana K, et al. Metabolic syndrome after HIV acquisition in South African women. JAcquir Immune Defic Syndr. 2016;73(4):438-445

63. Muyanja D, Muzoora C, Muyingo A, Muyindike W, Siedner MJ. High prevalence of metabolic syndrome and cardiovascular disease risk among people with HIV on stable ART in Southwestern Uganda. AIDS Patient Care STDs. 2016;30(1):4-10.

64. Guira O, Tiéno H, Diendéré AE, et al. Features of metabolic syndrome and its associated factors during highly active antiretroviral therapy in Ouagadougou (Burkina Faso). J Int Assoc Provid AIDS Care. 2016;15(2):159-163.

65. Eholié SP, Lacombe K, Krain A, et al. Metabolic disorders and cardiovascular risk in treatment-naive HIV-infected patients of Sub-Saharan origin starting antiretrovirals: impact of westernized lifestyle. AIDS Res Hum Retroviruses. 2015;31(4):384-392.
66. Tesfaye DY, Kinde S, Medhin G, et al. Burden of metabolic syndrome among HIV-infected patients in Southern Ethiopia. Diabetes Metab Syndr. 2014;8(2):102-107.

67. Ayodele OE, Akinboro AO, Akinyemi SO, et al. Prevalence and clinical correlates of metabolic syndrome in Nigerians living with human immunodeficiency virus/acquired immunodeficiency syndrome. Metab Syndr Relat Disord. 2012;10(5):373-379.

68. Zannou DM, Denoeud L, Lacombe K, et al. Incidence of lipodystrophy and metabolic disorders in patients starting non-nucleoside reverse transcriptase inhibitors in Benin. Antivir Ther. 2009;14(3):371-380.

69. Dimala CA, Atashili J, Mbuagbaw JC, Wilfred A, Monekosso GL. Prevalence of hypertension in HIV/AIDS patients on highly active antiretroviral therapy (HAART) compared with HAART-naive patients at the Limbe regional hospital, Cameroon. PLoS One. 2016;11(2):e0148100.

70. Longo-Mbenza B, et al. Relationship between younger age, autoimmunity, cardiometabolic risk, oxidative stress, HAART, and ischemic stroke in Africans with HIV/AIDS. ISRN Cardiol. 2011;2011:897908.

71. Tchounga BK, Hønge BL, Eholie SP, et al; IeDEA West Africa Collaboration. Effect of sex and age on outcomes among HIV-2 infected patients starting antiretroviral therapy in West Africa. AIDS. 2016;30(17): 2707-2714.

72. Feleke Y, Fekade D, Mezegebu Y. Prevalence of highly active antiretroviral therapy associated metabolic abnormalities and lipodystrophy in HIV infected patients. Ethiop Med J. 2012;50(3):221-230.

73. Diouf A, Cournil A; Groupe d'étude de la Cohorte ANRS 1215. Prevalence of metabolic complications after 10 years of antiretroviral treatment in Senegal. Bull Soc Pathol Exot. 2014;107(4):234-237. [Article in French]

74. Frantz JM, Murenzi A. The physical activity levels among people living with human immunodeficiency virus/acquired immunodeficiency syndrome receiving high active antiretroviral therapy in Rwanda. SAHARA J. 2013;10(3-4):113-118.

75. Ngatchou W, Lemogoum D, Ndobo $P$, et al. Increased burden and severity of metabolic syndrome and arterial stiffness in treatment-naive HIV+ patients from Cameroon. Vasc Health Risk Manag. 2013;9:509-516.

76. Berhane T, Yami A, Alemseged F, et al. Prevalence of lipodystrophy and metabolic syndrome among HIV positive individuals on highly active anti-retroviral treatment in Jimma, South West Ethiopia. Pan Afr Med J. 2012;13:43.

77. Armstrong C, Liu E, Okuma J, et al. Dyslipidemia in an HIV-positive antiretroviral treatment-naive population in Dar es Salaam, Tanzania. J Acquir Immune Defic Syndr. 2011;57(2):141-145.

78. Bekolo CE, Nguena MB, Ewane L, Bekoule PS, Kollo B. The lipid profile of HIV-infected patients receiving antiretroviral therapy in a rural Cameroonian population. BMC Public Health. 2014;14:236.

79. Ngala RA, Fianko K. Dyslipidaemia and dysglycaemia in HIV-infected patients on highly active anti-retroviral therapy in Kumasi Metropolis. Afr Health Sci. 2013;13(4):1107-1116.

80. Dave JA, Levitt NS, Ross IL, Lacerda M, Maartens G, Blom D. Antiretroviral therapy increases the prevalence of dyslipidemia in South African HIV-infected patients. PLoS One. 2016;11(3):e0151911.

81. Julius H, Basu D, Ricci E, et al. The burden of metabolic diseases amongst HIV positive patients on HAART attending The Johannesburg Hospital. Curr HIV Res. 2011;9(4):247-252.

82. Lesi OA, Soyebi KS, Eboh CN. Fatty liver and hyperlipidemia in a cohort of HIV-positive Africans on highly active antiretroviral therapy. J Natl Med Assoc. 2009;101(2):151-155.

83. Salami AK, Akande AA, Olokoba AB. Serum lipids and glucose abnormalities in HIV/AIDS patients on antiretroviral therapies. West Afr $J$ Med. 2009;28(1):10-15.

84. Muronya W, Sanga E, Talama G, Kumwenda JJ, van Oosterhout JJ. Cardiovascular risk factors in adult Malawians on long-term antiretroviral therapy. Trans R Soc Trop Med Hyg. 2011;105(11):644-649.

85. Ahmed MH, Woodward C, Mital D. Metabolic clinic for individuals with HIV/AIDS: a commitment and vision to the future of HIV services. Cardiovasc Endocrinol. 2017;6(3):109-112. 


\section{Publish your work in this journal}

HIV/AIDS - Research and Palliative Care is an international, peerreviewed open access journal focusing on advances in research in HIV, its clinical progression and management options including antiviral treatment, palliative care and public healthcare policies to control viral spread. The journal is included in PubMed. The manuscript man-

Submit your manuscript here: https://www.dovepress.com/hivaids---research-and-palliative-care-journal

agement system is completely online and includes a very quick and fair peer-review system, which is all easy to use. Visit http://www.dovepress com/testimonials.php to read real quotes from published authors. 